\title{
Electrical and Optical Properties of $\mathrm{Sb}_{2} \mathrm{O}_{3} \mathrm{~B}_{2} \mathrm{O}_{3} \mathrm{Bi}_{2} \mathrm{O}_{3} \mathrm{TeO}$ Glass System
}

\section{Ghada Adel}

Physics Department, Faculty of Science, Al-Azhar University (girls branch), Nasr City, Cairo, Egypt

$\mathbf{T}$

HE OPTICAL and electrical properties of $\mathbf{x} \mathrm{Sb}_{2} \mathrm{O}_{3}(35-\mathrm{x}) \mathrm{B}_{2} \mathrm{O}_{3} 60 \mathrm{Bi}_{2} \mathrm{O}_{3} 5 \mathrm{TeO}_{2}$ glass system (where, $x=10,20,30$ ) have been studied. It was found that the values of optical energy gap and activation energy of conduction decrease by increasing $\mathrm{Sb}_{2} \mathrm{O}_{3}$ content for all the studied samples. While as the values of refractive index, real dielectric constant ,molar polarizability ,oxide ion polarizability, optical basicity, third order nonlinear optical susceptibility increase by increasing $\mathrm{Sb}_{2} \mathrm{O}_{3}$ content. The high values of third order nonlinear optical susceptibility for all the studied samples, were found to be in the range (3.827-8.219) $\times 10^{-12} \mathrm{esu}$, which is larger than that of pure silica glass.Finally, it has been suggested that all the studied samples are promising materials for nonlinear optical requests.

Keywords: Density, Molar volume, Optical basicity, Optical and electrical properties.

\section{Introduction}

Tellurium oxide glasses have attracted much care because of their optical requests due to their high linear and nonlinear refractive indices and high nonlinear optical susceptibility [1]. The structure, electrical and optical properties of tellurium oxide glasses have been studied by many authors [2-6]. Also, Bismuth oxide glasses have been carried out because of their potential applications in optoelectronics and photonics [7]. Antimony oxide glasses have been given much attention because of their practical applications in nonlinear optical devices [8]. Borate glasses have been attracted attention due to their potential applications in the fields of linear and nonlinear optics and correlated techniques [9]. It was found [10] that the third order nonlinear susceptibility of $\mathrm{Sb}_{2} \mathrm{O}_{3} \quad \mathrm{~B}_{2} \mathrm{O}_{3}$ glasses increase rapidly by increasing $\mathrm{B}_{2} \mathrm{O}_{3}$ content. It has been found $[11,12]$ that $\mathrm{TeO}_{2} \mathrm{Bi}_{2} \mathrm{O}_{3} \mathrm{~B}_{2} \mathrm{O}_{3}$ glasses have narrow optical energy gap, high refractive index, and high third order nonlinear optical susceptibility. In the present article, the optical and electrical properties of $\mathrm{xSb}_{2} \mathrm{O}_{3}(35-\mathrm{x}) \mathrm{B}_{2} \mathrm{O}_{3} 60 \mathrm{Bi}_{2} \mathrm{O}_{3} 5 \mathrm{TeO}_{2}$ glass system (where, $\mathrm{x}=10,20,30$ ) have been studied.

\section{Experimental Details}

Proper weights of $\mathrm{Sb}_{2} \mathrm{O}_{3}, \mathrm{~B}_{2} \mathrm{O}_{3}, \mathrm{Bi}_{2} \mathrm{O}_{3}$ and $\mathrm{TeO}_{2}$ in accurate molar ratio were mixed to obtain uniform acceptable fine powder and then, placed in a porcelain crucible and heated in an electric furnace whose temperature was elevated in steps to $1100^{\circ} \mathrm{C}$ for half an hour. Then, the molten samples were rapidly cooled to room temperature by pouring it onto a cooper plate and successively pressing it with another to get glasses. The studied samples have been characterized by the X-ray diffraction (XRD). All the samples reveal non-crystalline nature as no noticeable peak was detected in their (XRD) spectra. The reflection and the transmission of all the samples in the wave length (400-1100nm) were measured using a computerized recording spectrophotometer (type Jasco, V-570). The dc conductivity was measured using a programmable electrometer model Keithley 617) which measure the resistance of the sample directly.

ghadahelmy@outlook.com 


\section{Results and Discussions}

Density and molar volume

The density of the samples was calculated using this equation:

$$
\mathrm{d}=0.8635\left[\mathrm{~W}_{\mathrm{a}} /\left(\mathrm{W}_{\mathrm{a}}-\mathrm{W}_{\mathrm{b}}\right)\right]
$$

where, $\mathrm{d}$ is the density of the glass sample, $\mathrm{W}_{\mathrm{a}}$ is the weight of the glass sample in air, $\mathrm{W}_{\mathrm{b}}$ is the weight of the glass sample in toluene and 0.8635 is the density of toluene. The values of density for all the studied samples are listed in Table 1.

The molar volume $=($ Total molecular weight $) /$ ( density)

The values of molar volume for all the studied samples are listed in Table 1 . It is clear that the values of the density increase because the values of molecular weight increase by increasing $\mathrm{Sb}_{2} \mathrm{O}_{3}$ content. Also, the values of molar volume increase for all the studied samples. This can be attributed to the $\mathrm{Sb}_{2} \mathrm{O}_{3}$ ionic radii $(0.900 \mathrm{~A})$ higher than the $\mathrm{B}_{2} \mathrm{O}_{3}$ ionic radii $(0.200 \mathrm{~A})$ accordingly affected expansion of allowed volume [13].

\section{Optical energy gap}

The optical transmission and reflection spectra for all the studied samples are shown in Fig. 1 and 2 . The absorption coefficient $\alpha$ was calculated [14] by using the measured values of the reflection ( $\mathrm{R}$ ) and the transmission (T) as follows,

$$
\alpha=(1 / t)(\ln (1-R) / T)
$$

where $t$ is thickness of the sample.

TABLE 1. The values of density, molecular weight and molar volume for all the studied samples.

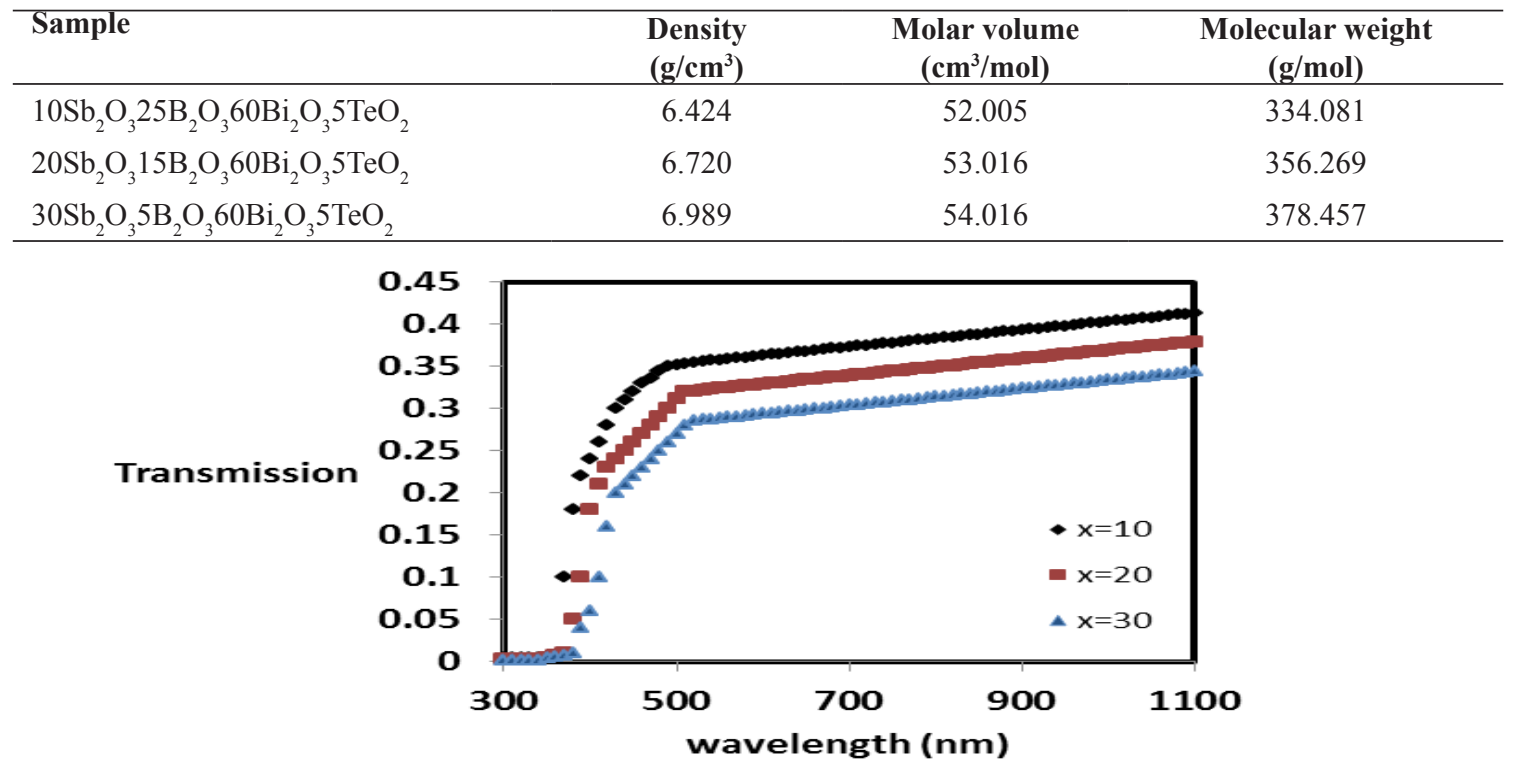

Fig. 1. The optical transmission spectra for all the studied samples.

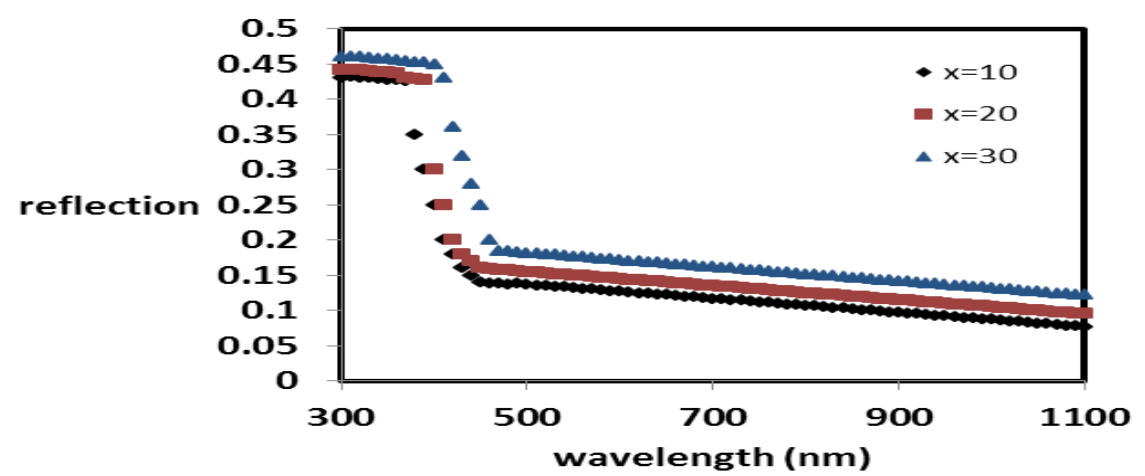

Fig. 2. The optical reflection spectra for all the studied samples. 


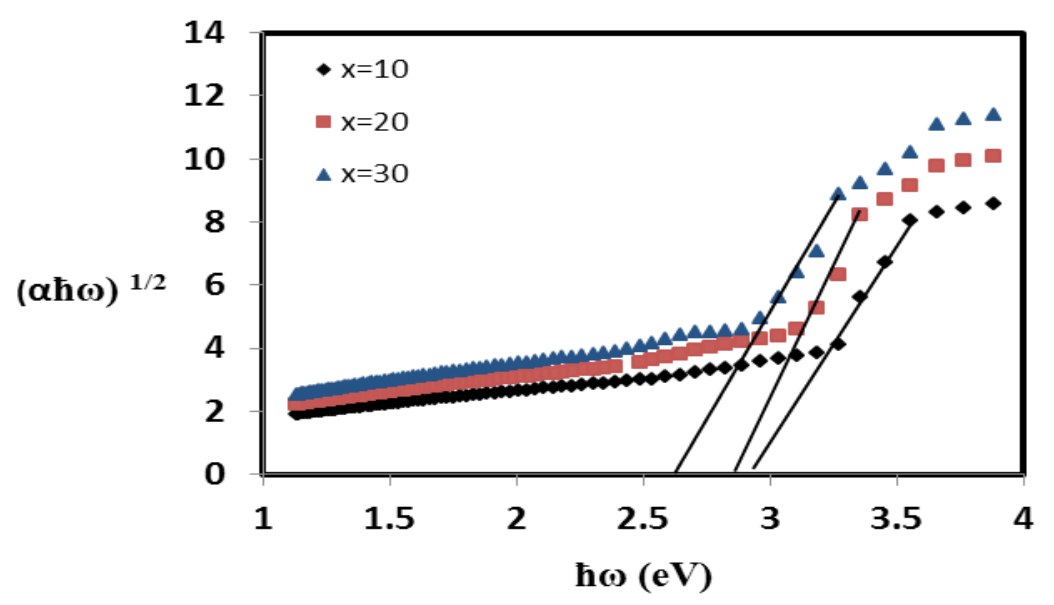

Fig. 3.The relation between $(\alpha \hbar \omega) 1 / 2$ and $\hbar \omega$ for all the studied samples.

TABLE 2. The values of the optical energy gap, molar refraction molar polarizability for all the studied samples.

\begin{tabular}{lccc}
\hline Sample & $\begin{array}{c}\text { The optical } \\
\text { energy gap } \\
(\mathbf{e V})\end{array}$ & $\begin{array}{c}\text { Molar } \\
\text { refraction } \\
(\mathbf{c m} / \mathbf{m o l})\end{array}$ & $\begin{array}{c}\text { Molar } \\
\text { polarizability } \\
\left(\AA^{3}\right)\end{array}$ \\
\hline $10 \mathrm{Sb}_{2} \mathrm{O}_{3} 25 \mathrm{~B}_{2} \mathrm{O}_{3} 60 \mathrm{Bi}_{2} \mathrm{O}_{3} 5 \mathrm{TeO}_{2}$ & 2.94 & 29.61 & 12.72 \\
$20 \mathrm{Sb}_{2} \mathrm{O}_{3} 15 \mathrm{~B}_{2} \mathrm{O}_{3} 60 \mathrm{Bi}_{2} \mathrm{O}_{3} 5 \mathrm{TeO}_{2}$ & 2.86 & 31.71 & 13.08 \\
$30 \mathrm{Sb}_{2} \mathrm{O}_{3} 5 \mathrm{~B}_{2} \mathrm{O}_{3} 60 \mathrm{Bi}_{2} \mathrm{O}_{3} 5 \mathrm{TeO}_{2}$ & 2.62 & 33.74 & 13.71 \\
\hline
\end{tabular}

Mott and Davis [15] proposed the following relation between the absorption coefficient $\alpha(\omega)$ and the photon energy $\hbar \omega$ of the incident radiation, for indirect transitions this relation can be written as follows,

$$
\alpha \hbar \omega=\beta\left(\hbar \omega-\mathrm{E}_{\mathrm{opt}}\right)^{2}
$$

The values of optical energy gap can be determined as the intersection between $(\alpha \hbar \omega)^{1 / 2}$ and $\hbar \omega$ as shown in Fig. 3. It was found that the values of the optical energy gap which are listed in Table 2 decrease by increasing $\mathrm{Sb}_{2} \mathrm{O}_{3}$ content for all the studied samples. As a result of the replacement of $\mathrm{B}_{2} \mathrm{O}_{3}$ with $\mathrm{Sb}_{2} \mathrm{O}_{3}$, the structural changes take place inside the glass. As $\mathrm{Sb}_{2} \mathrm{O}_{3}$ in the glass matrix increases, $\mathrm{B}-\mathrm{O}-\mathrm{Bi}$ is replaced with $\mathrm{Sb}-\mathrm{O}-\mathrm{Bi}$. These structural changes will result in shifting the valence band maximum to higher energies, thus decreasing the band gap of the glass system..

\section{The third order nonlinear susceptibility}

The third order nonlinear susceptibility $\chi^{(3)}$

( in e.s.u units) can be calculated from values of the optical energy gap as follows [16],

$$
\chi^{(3)}=\frac{\left(1.4 \times 10^{-11}\right)}{\left(\left(E_{\text {opt }}-1.96\right)\left(E_{\text {opt }}-1.31\right)\left(E_{\text {opt }}-0.65\right)\right)}
$$

It was found that the values of third order nonlinear susceptibility which are listed in Table 3 are higher than that of pure silica glass $\left(2.8 \times 10^{-}\right.$ ${ }^{12}$ e.s.u), which means that all the studied samples are promising materials for nonlinear optical devices. Also, It was noticed that the values of third order nonlinear optical susceptibility increase by increasing $\mathrm{Sb}_{2} \mathrm{O}_{3}$ content as a result of decreasing the values of optical energy gap for all the studied samples.

\section{The refractive index}

The refractive index $\mathrm{n}$ can be calculated [17] according to the following equations

$$
\mathrm{n}=\left(1+\mathrm{R}^{1 / 2}\right) /\left(1-\mathrm{R}^{1 / 2}\right)
$$

Figure 4 show the dependence of $n$ with wave length $\lambda$. It is clear that the refractive index increase by increasing $\mathrm{Sb}_{2} \mathrm{O}_{3}$ content . The refractive index is related to the polarizability of oxide ions [18]. 
The polarizability of oxide ions and the optical bacisity

The polarizability of oxide ions can be calculated as follows [13], polarizability of oxide ion $=1.67 /(1.67$-optical basicity $)$ and the optical basicity can be calculated as following [13] ,

Optical basicity $=x\left(\mathrm{Sb}_{2} \mathrm{O}_{3}\right) \Lambda\left(\mathrm{Sb}_{2} \mathrm{O}_{3}\right)+\mathrm{x}\left(\mathrm{B}_{2} \mathrm{O}_{3}\right)$ $\Lambda\left(\mathrm{B}_{2} \mathrm{O}_{3}\right)+\mathrm{x}\left(\mathrm{Bi}_{2} \mathrm{O}_{3}\right) \Lambda\left(\mathrm{Bi}_{2} \mathrm{O}_{3}\right)+\mathrm{x}\left(\mathrm{TeO}_{2}\right) \Lambda\left(\mathrm{TeO}_{2}\right)$

Where $\mathrm{x}\left(\mathrm{Sb}_{2} \mathrm{O}_{3}\right) \times\left(\mathrm{B}_{2} \mathrm{O}_{3}\right), \mathrm{x}\left(\mathrm{Bi}_{2} \mathrm{O}_{3}\right)$ and $\mathrm{x}\left(\mathrm{TeO}_{2}\right)$ are the equivalent fraction of the different oxides. And $\Lambda\left(\mathrm{Sb}_{2} \mathrm{O}_{3}\right), \Lambda\left(\mathrm{B}_{2} \mathrm{O}_{3}\right), \Lambda\left(\mathrm{Bi}_{2} \mathrm{O}_{3}\right)$ and $\Lambda\left(\mathrm{TeO}_{2}\right)$, are the optical basicity values of the constituent oxides. The values of optical basicity and the values of polarizability of oxide ions for all the studied samples are listed in Table 3.

It is clear that, all the studied samples are more basic and more polarized. Also, the increase in refractive index is most likely due to the increase in oxide ion polarizability for all the studied samples.

\section{The real dielectric constant}

Also, the real dielectric constant $\varepsilon$ ' can be calculated [17] using the following equations,

$$
\varepsilon^{\prime}=\mathrm{n}^{2}-\mathrm{k}^{2}
$$

where $\mathrm{k}=\alpha \lambda /(4 \pi)$ is the extinction coefficient.

Figure 5 shows the dependence of the real dielectric constant with wavelength $\lambda$. The optical dielectric constant is related to the polarizability [18].

\section{The molar polarizability}

The molar polarizability $\left(\alpha_{\mathrm{m}}\right)$ can be calculated [13] as a function of molar refraction $\left(\mathrm{R}_{\mathrm{m}}\right)$,

$$
\alpha_{\mathrm{m}}=\left(\mathrm{R}_{\mathrm{m}} / 2.52\right)
$$

The optical energy gap is related to molar refraction [13].

$$
\mathrm{R}_{\mathrm{m}}=\mathrm{V}_{\mathrm{m}}\left[1-\left(\mathrm{E}_{\mathrm{opt}} / 20\right)^{1 / 2}\right]
$$

TABLE 3. The values of optical basicity, oxide ion polarizability ,activation energy of conduction and third order nonlinear susceptibility for all the studied samples.

\begin{tabular}{ccccc}
\hline Sample & $\begin{array}{c}\text { Optical } \\
\text { basicity }\end{array}$ & $\begin{array}{c}\text { Oxide ion } \\
\text { polarizability }\end{array}$ & $\begin{array}{c}\text { Activation } \\
\text { energy of } \\
\text { conduction (eV) }\end{array}$ & $\begin{array}{c}\text { Third order } \\
\text { nonlinear } \\
\text { susceptibility (esu) }\end{array}$ \\
\hline $10 \mathrm{Sb}_{2} \mathrm{O}_{3} 25 \mathrm{~B}_{2} \mathrm{O}_{3} 60 \mathrm{Bi}_{2} \mathrm{O}_{3} 5 \mathrm{TeO}_{2}$ & 0.989 & 2.452 & 1.25 & $3.827 \times 10^{-12}$ \\
$20 \mathrm{Sb}_{2} \mathrm{O}_{3} 15 \mathrm{~B}_{2} \mathrm{O}_{3} 60 \mathrm{Bi}_{2} \mathrm{O}_{3} 5 \mathrm{TeO}_{2}$ & 1.069 & 2.779 & 1.19 & $4.541 \times 10^{-12}$ \\
$30 \mathrm{Sb}_{2} \mathrm{O}_{3} 5 \mathrm{~B}_{2} \mathrm{O}_{3} 60 \mathrm{Bi}_{2} \mathrm{O}_{3} 5 \mathrm{TeO}_{2}$ & 1.149 & 3.205 & 1.10 & $8.219 \times 10^{-12}$ \\
\hline
\end{tabular}

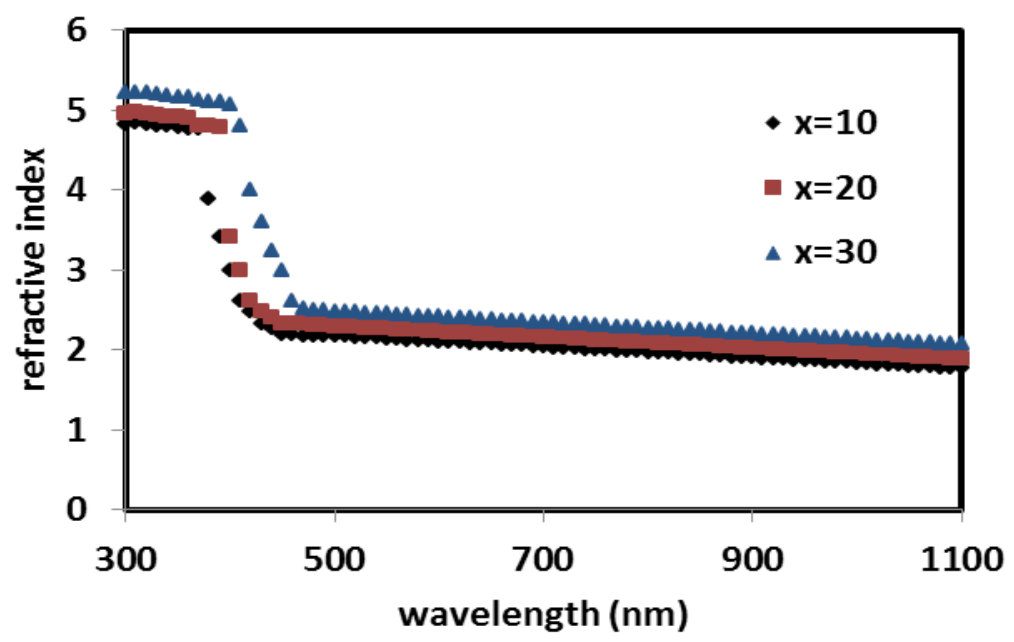

Fig. 4. The refractive index for all the studied samples. 
The values of molar refraction and molar polarizability are listed in Table 2 . It is clear that the values of the dielectric constant increase as a result of increasing the polarizability of all the studied samples.

\section{dc electrical conductivity}

The dc electrical conductivity $\sigma$ can be calculated [14] as follows,

$$
\sigma=\sigma_{0} \exp \left[-\Delta \mathrm{E} / \mathrm{K}_{\mathrm{B}} \mathrm{T}\right]
$$

Where $\sigma_{0}$ is the pre-exponential factor, $\Delta \mathrm{E}$ is the activation energy of conduction; $\mathrm{K}_{\mathrm{B}}$ is the Boltzmann's constant. Figure 6 shows the dc electrical conductivity for all the studied samples. The activation energy of conduction can be calculated from the slope of the straight line. The values of the activation energy of conduction are listed in Table 3. It was found that by increasing $\mathrm{Sb}_{2} \mathrm{O}_{3}$ content the activation energy of conduction decreased for all the studied samples which agrees with the optical energy gap. The reduction in the activation energy of conduction is most likely due to the replacement of $\mathrm{B}-\mathrm{O}-\mathrm{Bi}$ by $\mathrm{Sb}-\mathrm{O}-\mathrm{Bi}$.

\section{Conclusions}

From the present study of $\mathrm{xSb}_{2} \mathrm{O}_{3}(35-\mathrm{x}) \mathrm{B}_{2} \mathrm{O}_{3}$ $60 \mathrm{Bi}_{2} \mathrm{O}_{3} 5 \mathrm{TeO}_{2}$ glass system, it was found that both of the values of density and molar volume increase by increasing $\mathrm{Sb}_{2} \mathrm{O}_{3}$ content. Also the values of optical energy gap and the values of the activation energy of conduction decrease for all the studied samples. While the values of refractive index and optical dielectric constant increase.

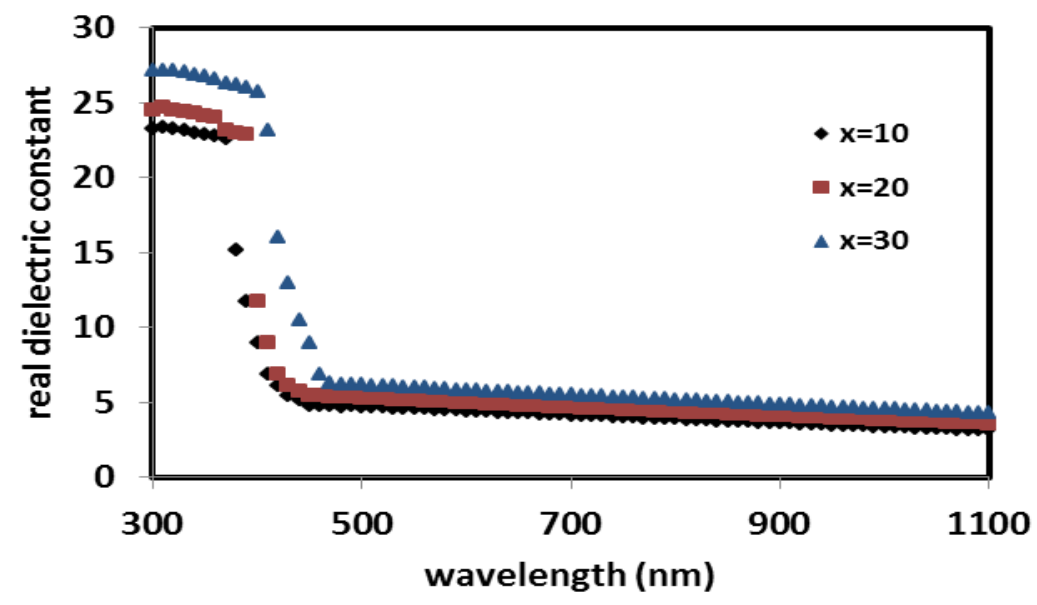

Fig. 5.The relation between the real dielectric constant and wavelength.

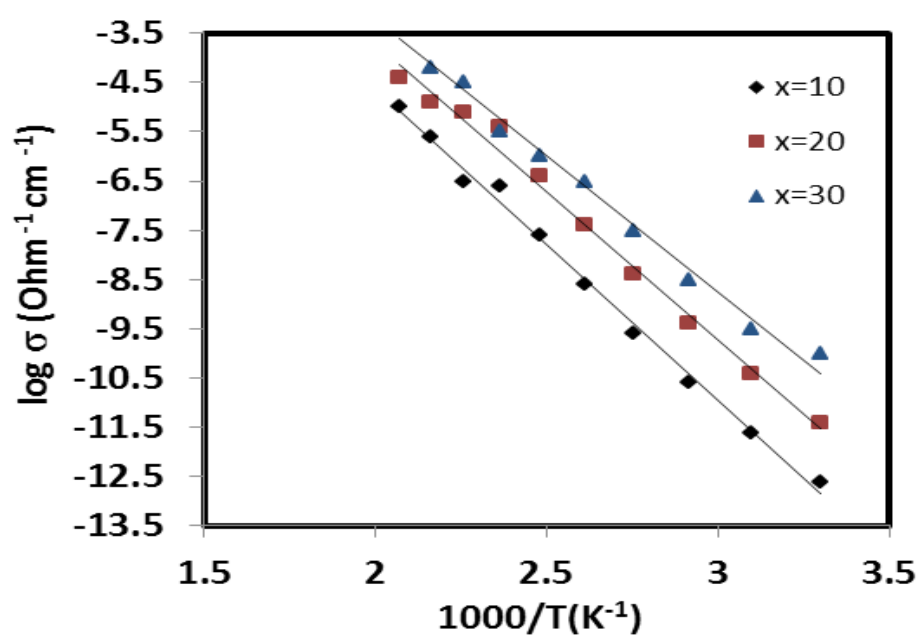

Fig. 6. The dc electrical conductivity for all the studied samples. 
The present glasses become more basic and more polarized by increasing $\mathrm{Sb}_{2} \mathrm{O}_{3}$ content. Finally, it was found that, all the studied glasses which have high refractive index, high optical basicity, high oxide ion polarizability and high third order nonlinear susceptibility are promising materials for nonlinear optical devices.

\section{References}

1. R. El Mallawany, Tellurite glasses hand bookphysical properties and data, CRC press, (2001).

2. N. Cupta, A. Kaur, A. Khanna, F. Gonzalez, C.Resquera, R.Iordanovo, B. Chen, Structure property correlation in $\mathrm{Tio}_{2} \mathrm{Bi}_{2} \mathrm{O}_{3} \mathrm{~B}_{2} \mathrm{O}_{3} \mathrm{TeO}_{2}$ glasses. J. of Non Crystalline Solids, 470, 168-177 (2017).

3. S.H. Elazomi, H. A.A. Sidek, Y.S. Rammach, K.A. Matori, M.H.M. Zaid, Effect of Pb on optical properties of tellurite glass, Results in Physics, 8, 16-25 (2018).

4. S.H. Farhan, Study of some physical and optical properties of $\mathrm{Bi}_{2} \mathrm{O}_{3} \quad \mathrm{TeO}_{2} \quad \mathrm{~V}_{2} \mathrm{O}_{5}$ glasses, Australian J. of Applied Science., 11(2017)171-178.

5. S.E. Ibrahim,Y.S. Ramnal , I.Z. Hager, R. El Mallawany, Uv and electrical properties of $\mathrm{TeO}_{2}-\mathrm{WO}_{3} \mathrm{LiO}-\mathrm{Nb}_{2} \mathrm{O}_{5} / \quad \mathrm{Sm}_{2} \mathrm{O}_{3} / \quad \mathrm{Pr}_{6} \mathrm{O}_{11} / \mathrm{ErO}_{3}$ glasses, J. of Non Crystalline Solids, 498, 443 (2018).

6. F.M. Fudzi ,H.M. Kamari, F.D. Muhamad, A.A. Latif, Z. Ismail Structural and optical properties of Zinc Borotellurite glass Co dopped with Lanthanum and silver oxide, J. of Material Science and Chemical Engineering 6, 18-23 (2018).

7. T. Maeder, Review of $\mathrm{Bi}_{2} \mathrm{O}_{3}$ based glasses for electronics and related applications, International Materials Review, 58, 3-40 (2012).

8. G. Justin, S. Prabakar, T. Karl, The effects of antimony on the structure of alkaline earth alimino borosilicate glasses, $J$. of Non Crystalline Solids, 349, 276-284 (2004).
9. D. Ehrt, Structure, properties and applications of borate glasses, Glass Technlogy, 41, 182 (2000).

10. K.Terashima, T, Hshimoto, T. Uchino, S.H. Kim, T. Yoko, Sructure and nonlinear properties of $\mathrm{Sb}_{2} \mathrm{O}_{3} \mathrm{~B}_{2} \mathrm{O}_{3}$ binary glasses. $J$. of the Ceramic Society of Japan , 104, 10081014 (1996).

11. T. R. Tasheva, V.V. Dimitrov, Synthesis, structure and nonlinear optical properties of $\mathrm{Bi}_{2} \mathrm{O}_{3} \mathrm{TeO}_{2} \quad \mathrm{~B}_{2} \mathrm{O}_{3}$, Bulgarian Chemical Communications, 49, 43-48 (2017).

12. H. Tomohrn, Optical properties of $\mathrm{Bi}_{2} \mathrm{O}_{3} \mathrm{TeO}_{2}$ $\mathrm{B}_{2} \mathrm{O}_{3}$ glasses, J. of Non Crystalline Solids, 357 (2011)2857-2862.

13. V.Dimitrov and T. Komatsu, "An interpretation of optical properties of oxide and oxide glasses in terms of the electronic ion polarizability and average single bond strength, J. of University of Chemical Technology and Metallurgy, 43, 219-250 (2010).

14. N.F. Mott , E.A.Davis , Electronic processes in non crystalline materials, Oxford university press, Oxford (1979).

15.J. Tauc, Amorphousb and liquid semiconductors. Plenum, New York , P.159 (1974).

16. T. Tashva, V. Dimitrov, Synthesis, optical properties and structure of $\mathrm{NiO} \mathrm{BaO} \mathrm{V}_{2} \mathrm{O}_{5}$ glasses., J. of Chem. Tech. and Metallargy, 52, 369-378 (2017).

17. S.M. Salem , I. Shaltout ,Structure ,electrical and optical properties of $\mathrm{ZnO}$-substituted $\mathrm{PbO}$ for the $\mathrm{Er}^{+3} / \mathrm{Yb}^{+3}$ co-doped $\mathrm{Bi}_{2} \mathrm{O}_{3}-\mathrm{GeO}_{2}-$ $\mathrm{Na}_{2} \mathrm{O}$ glass system, J. of Material Science 45, 1837-1845 (2010).

18. M.N. Azlan, M.K. Hlimah, S.Z. Shafinas, W.M. Daud, "Polarizability and optical basicity of $\mathrm{Er}^{3+}$ ions doped tellurite based glasses", Chalcogenide letters, 11, 319-335 (2014).

(Received: 6/10/2018; accepted: 22/11/2018) 
الخواص الكهربية والضوئية للنظام الزجاجى $\mathrm{Sb}_{2} \mathrm{O}_{3} \mathrm{~B}_{2} \mathrm{O}_{3} \mathrm{Bi}_{2} \mathrm{O}_{3} \mathrm{TeO}_{2}$

تمت در اسة الخواص البصرية و الكهربائية للنظام الزجاجي حيث.

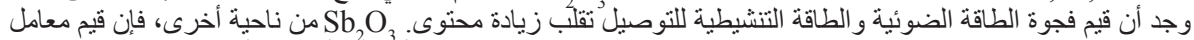

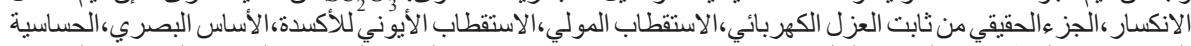

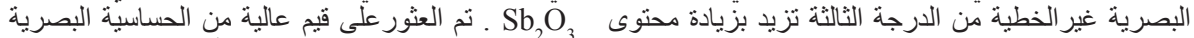

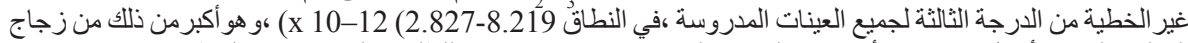
السيليكا النقي. وأخيرًا،تم القتر اح أن جميع العينات المدروسة هي مواد واعدة للطلبات البصرية غير الخطية. 